7-1-2019

\title{
Corporate Governance and the Cult of Agency
}

\author{
J.B. Heaton
}

Follow this and additional works at: https://digitalcommons.law.villanova.edu/vlr

Part of the Business Organizations Law Commons

\section{Recommended Citation}

J.B. Heaton, Corporate Governance and the Cult of Agency, 64 Vill. L. Rev. 201 (2019).

Available at: https://digitalcommons.law.villanova.edu/vlr/vol64/iss2/2

This Article is brought to you for free and open access by Villanova University Charles Widger School of Law Digital Repository. It has been accepted for inclusion in Villanova Law Review by an authorized editor of Villanova University Charles Widger School of Law Digital Repository. 


\title{
CORPORATE GOVERNANCE AND THE CULT OF AGENCY
}

\author{
J.B. HEATON*
}

"The agency approach has pointed in some intriguing directions, but it fares poorly if judged by asking what it is that would be a counter observation or count as evidence against it. To the contrary, no phenomenon seems beyond the reach of 'agency costs' and at times the phrase takes on more of the trappings of an incantation than an analytical tool." 1

Stephen A. Ross

\section{INTRODUCTION}

$\mathrm{T}$ HERE is no agency problem between a corporation's shareholders and a corporation's directors, officers, and managers. We know this because shareholders are not principals, and directors, officers, and managers are not shareholders' agents. While "the separation of ownership and control" rolls off the tongue too easily now, like an oft-repeated mantra, that separation is pure fiction. The law is crystal clear: separation is of ownership and ownership. Corporations own assets; shareholders own shares. A simple proof is by contradiction. If shareholders owned the corporation, then shareholders could not sue the corporation. But shareholders can sue the corporation. Therefore, shareholders do not own the corporation. Moreover, as lawyers have understood for hundreds of years, the separateness of shareholders and the corporation is fundamental to the corporation's usefulness as a method of organizing business.

What shareholders do (usually) have is the right to vote for the corporation's directors. That vote can be powerful. It can change who the directors are or the behavior of existing directors, but it does so as an election of officials in a sort of representative democracy: by putting in power (or putting in fear) those who are subject to the shareholder vote. At all times, however, elected directors have duties-including fiduciary duties-and protections-including the business judgment rule-that nearly always allow them to make decisions they view (or can plausibly claim to view) as being in the "long-run" interest of the corporation and its shareholders. They need not-except when they put the company up for sale-maximize current shareholder value. That is the reality, and economic and legal analysis that ignores it has little chance at relevance for the study of actual corporate behavior.

The agency-theory approach to corporate governance grew as corporations grew, built on the myth that the corporation was a fiction and that

* J.B. Heaton, P.C., jb@jbheaton.com.

1. Stephen A. Ross, Finance, in vol. 2, The New Palgrave: A Dictionary of Economics 334 (John Eatwell, Murray Milgate \& Peter Newman, eds. 1987). 
Villanova Law Review, Vol. 64, Iss. 2 [2019], Art. 2

shareholders effectively had a property right in the corporation's assets. Much as early civilizations explained real-world phenomena by their relationship with unseen deities, agency theorists tell tales of shareholders below and managers above, where shareholders struggle to keep peace with sacrifices (paying monitoring expenditures), managers make divine promises to behave (incurring bonding costs), but where shareholders ultimately are left to deal with the uncontrolled whim of the gods (remaining managerial discretion).

As with primitive religions, there is, in the end, no evidence that this mythical battle is real. Managers are usually loyal, probably because so much of the focus of existing corporate law is on the control of managerial disloyalty. Moreover, the business world is far more competitive than most agency-cost models assume, leaving little scope for managerial slack. What evidence shows instead is that managers suffer from cognitive biases; most importantly, they are too optimistic. Managerial optimism and the flexibility of corporate law explain most arguable failures to maximize current shareholder value. Scholarship in both economics and law would improve if researchers faced these realities and left the cult of agency behind.

Part I is straightforward but necessary, setting out the simple legal reality that we live in a world of separation of ownership and ownership, not of separation of ownership and control. Shareholders do not "own" the corporation and directors and officers are not "agents" of shareholder "principals." The corporation is not a convenient fiction-and certainly not a "nexus of contracts"-but a necessary and essential legal device to partition, lock-in, and shield the firm's assets from other entities including shareholders. Moreover, corporate law is flatly at odds with the asserted instruction the mythical shareholder-principal gives to her mythical manager-agent: maximize current shareholder value. Corporate law is clear that managers need not do so, except when the directors put the company up for sale. Instead, directors and officers are allowed and even encouraged to manage the corporation for longevity, under cover of doing so for the long-run interests of the shareholders. Theorists ignore these legal realities at their peril, because directors, officers, investors, and the many professionals who serve them live within these rules when they fight over corporate governance.

Part II explores the agency-cost paradigm for the study of the corporation. The agency-cost concept evolved from early objections to the profit-maximization assumption of neoclassical economics. Several economists, most notably Oliver Williamson, asserted-without empirical evidence-that managers maximizing their own utility would intentionally divert value to themselves and shirk the responsibilities of profit maximization, an approach that became known as managerial discretion. Soon, a few economists began separately to study the economics of agency relationships. Then, most famously, Michael C. Jensen and William H. Meckling 
argued that agency costs were everywhere and included the sum of expenditures by the principal to prevent diversions by her agent, expenditures by the agent to bond himself from making the expected diversions, and the remaining losses that would occur from the diversions the agent would make anyway. Because, as Stephen Ross's quote above suggests, the agency approach could explain most anything-good behavior was evidence of the success of the expenditures by principal and agent, while bad behavior was evidence of the unpreventable residual losses-agency explanations exploded. Soon, there was an agency-cost explanation for most anything. Agency theory took economists off the hook of learning corporate law, made economic analysis of the firm the study of games between shareholders and managers, and did so within a creative framework that facilitated mathematics-free narratives that made for a broad debate among academic economists and academic lawyers.

Part III brings us back to earth, arguing for the end of the cult of agency. Despite thousands of articles invoking agency theory, there is virtually no evidence that managers do not maximize current shareholder value because of managerial disloyalty. There likely are two reasons for this. First, much of the focus of existing corporate law is on the control of managerial disloyalty. It simply is not that hard to control managerial diversions of any meaningful size. Second, the business world is far more competitive than most agency-cost models assume, leaving little scope for managerial slack if the corporation is to survive.

Part IV argues that the empirical evidence is instead that managers, when they fail to maximize shareholder value, do so either because corporate law allows it, because managers are too optimistic about their abilities and the prospects of their firms, or both. Managerial optimism easily explains behaviors and mechanisms associated with agency theory and does so more parsimoniously and with sharper predictions. The path forward-a path that promises more relevance in real-world debates about, for example, hedge fund activism and other matters of corporate governance-recognizes both the separation of ownership and ownership, the flexibilities of corporate law, and the cognitive bias of managerial optimism that sometimes make managers less than current-shareholder-value maximizers.

Part V offers a brief conclusion urging corporate governance scholarship to abandon agency theory and embrace explanations that will prove useful in the real world.

\section{Legal and Economic Realities}

"Corporate managers are the agents of shareholders, a relationship fraught with conflicting interests." 2

2. Michael C. Jensen, Agency Costs of Free Cash Flow, Corporate Finance, and Takeovers, 76 Amer. Econ. Rev. 323, 323 (1986). 
Villanova Law Review, Vol. 64, Iss. 2 [2019], Art. 2

"Stockholders do not direct management's activities. Indeed, stockholders are explicitly denied power to interfere in management's activities. That they may not, or rationally should not, wish to do so does not detract from the distortion in characterizing management as their agent." ${ }^{3}$

\section{A. The Separation of Ownership and Ownership}

There is a too-obvious legal objection to agency in the theory of the firm: shareholders are not principals and directors and officers are not shareholders' agents. ${ }^{4}$ The law could not be clearer in this regard. There is not, as Adolph Berle and Gardiner Means claimed, a "separation of ownership and control." Shareholders own shares, they do not own the corporation or its assets. The moment of incorporation is a moment where the "body corporate" 6 becomes "separate and distinct" from those promoters who form it. ${ }^{7}$ At that moment, the corporation is owned by no one. Rather, it acts through its agents, and its business and affairs are decided by its directors, ${ }^{8}$ none of whom need be shareholders, ${ }^{9}$ and none of whom are agents of the shareholder or the corporation. ${ }^{10}$ Corporate officers are agents of the corporation, not the shareholders. ${ }^{11}$

This legal separateness is no fiction; it is all important. Incorporation is special precisely because it allows for separateness: a partitioning of a set

3. Victor Brudney, Corporate Governance, Agency Costs, and the Rhetoric of Contract, 85 Colum. L. Rev. 1403, 1428 (1985).

4. See, e.g., Lyman Johnson \& David Millon, Corporate Law After Hobby Lobby, 70 Bus. LAw. 1, 14 (2014) ("[T]he agency characterization also lacks legal foundation.").

5. Adolf A. Berle \& Gardiner C. Means, The Modern Corporation and Private Property 4 (1936).

6. See, e.g., Del. Code Ann. tit. 8, § 106 (2016) ("Upon the filing with the Secretary of State of the certificate of incorporation, executed and acknowledged in accordance with $\S 103$ of this title, the incorporator or incorporators who signed the certificate, and such incorporator's or incorporators' successors and assigns, shall, from the date of such filing, be and constitute a body corporate, by the name set forth in the certificate, subject to $\S 103(\mathrm{~d})$ of this title and subject to dissolution or other termination of its existence as provided in this chapter.").

7. See Stephen M. Bainbridge \& M. Todd Henderson, Limited Liability: A Legal and ECOnOmic Analysis 5 (2016) ("The first implication of corporate separateness is that corporations have a legally recognized personhood separate and distinct from its shareholders and other stakeholders.").

8. See, e.g., Del. Code Ann. tit. 8, § 141(a) (2016) ("The business and affairs of every corporation organized under this chapter shall be managed by or under the direction of a board of directors ....").

9. See, e.g., Del. Code ANN. tit. 8, § 141(b) ("Directors need not be stockholders unless so required by the certificate of incorporation or the bylaws.").

10. See Restatement (Third) of Agency $\$ 1.01 \mathrm{cmt}$. f(2) (Am. Law Inst. 2006) ("Although a corporation's shareholders elect its directors and may have the right to remove directors once elected, the directors are neither the shareholders' nor the corporation's agents as defined in this section, given the treatment of directors within contemporary corporate law in the United States.").

11. See id. at cmt. c. 
of assets, locked-in by shareholders who then cannot pull them out, ${ }^{12}$ and shielded from the claims of shareholders' creditors, who otherwise might rip the corporation apart to satisfy their claims. ${ }^{13}$ These benefits of incorporation were recognized by the seventeenth century along with all other well-known features of corporate personality, such as limited liability. ${ }^{14}$

\section{B. Corporate Law's (Barely Hidden) Directives}

Since the 1960s and early 1970s, the view in financial economicsand apparently among many shareholders-has been that it is the job of corporate managers to maximize the current value of the firm. ${ }^{15}$ This is the same rule drilled into M.B.A. students today. ${ }^{16}$

The directive in the M.B.A. classroom has never been the directive in the courtroom. Delaware case law, for example, requires directors to max-

12. See Margaret M. Blair, Locking in Capital: What Corporate Law Achieved for Business Organizers in the Nineteenth Century, 51 UCLA L. Rev. 387, 392 (2003) (stressing "the role that incorporation played in establishing a pool of assets that was not subject to being liquidated or dissolved by any of the individual participants who might want to recover their investment"); see also Lynn A. Stout, The Corporation as a Time Machine: Intergenerational Equity, Intergenerational Efficiency, and the Corporate Form, 38 Seattle U. L. Rev. 685, 688 (2015) ("Put simply, once you use your money to purchase stock in a company, your money becomes the company's money. You have no legal power to demand it back.").

13. See Henry Hansmann \& Reiner Kraakman, The Essential Role of Organizational Law, 110 YALE L. J. 387, 390 (2000) ("The truly essential aspect of asset partitioning is, in effect, the reverse of limited liability-namely, the shielding of the assets of the entity from claims of the creditors of the entity's owners or managers. This means that organizational law is much more important as property law than as contract law.").

14. See Bishop Carlton Hunt, The Development of the Business CorporaTION IN ENGLAND, 1800-1867 3 (1936) ("[I]n the seventeenth century the commercial advantages flowing from and incident to incorporation were becoming clear: perpetuity or, at least, continuity of existence (and management) independent of that of members; ease of suit against third parties or against members; transferable shares; unlimited divisibility of the equities; and the distinct demarcation of liability for the debts of a corporation, as well as of that for the debts of its shareholders." (emphasis added)). Hunt observed that " $[\mathrm{t}]$ he importance of non-liability for the debts of members was urged, for example, in the petition of the Silk Throwsters for incorporation in 1692: 'If such an undertaking should be carried on only by articles of partnership, the stock will be liable to the particular and private debts of the several partners, and subject to be torn to pieces by the bankruptcy of any of them.'" Id. at 3-4 n.1.

15. See, e.g., Alexander A. Robichek \& Stewart C. Myers, Optimal Financing DECisions 2 (1965) ("This book assumes that the objective of the financial manager is to maximize the value of the firm to its stockholders."); see also EUGENE F. FAMA \& Merton H. Miller, The Theory of Finance 69 (1972) (management should "maximize the current market value" of the firm, calling it the "market value rule").

16. See Richard A. Brealey, Stewart C. Myers \& Franklin Allen, Principals of Corporate Finance 7 (2014) ("A smart and effective manager makes decisions that increase the current value of the company's shares and the wealth of its stockholders.”). 
imize the "long run interests of shareholders"; 17 they have no duty (absent a change of control transaction) to do that which "will best maximize the corporation's current stock price." 18 As Vice Chancellor Travis Laster put it:

The fiduciary obligation to maximize the value of the corporation for the benefit of its stockholders does not mean that directors must sacrifice greater value that can be achieved over the long term in pursuit of short-term strategies, and it certainly does not mean that directors must attempt to maximize the ... public company's stock price on a daily or quarterly basis. The fiduciary relationship requires that directors act prudently, loyally, and in good faith to maximize the corporation's value over the longterm for its stockholders' benefit. ${ }^{19}$

I have argued elsewhere that the short term-long term rhetoric that Delaware courts use in their corporate-law opinions masks the real contest, one between a rational desire by clear-sighted shareholders for shareholder value maximization, on the one hand, and a desire by courts and others for long-term corporate survival-on the other. ${ }^{20}$ Delaware courts use the rhetoric of the "long term" to take pressure off directors to do exactly that which finance professors teach their M.B.A. students. In reality,

directors, when acting deliberately, in an informed way, and in the good faith pursuit of corporate interests, may follow a course designed to achieve long-term value even at the cost of immediate value maximization. ${ }^{21}$

Delaware's current Chief Justice, former Chancellor Leo Strine, has tipped his hand in recent commentary, revealing that what he wants is for corporations to focus on longevity, not shareholder-value maximization. Consider some of his statements:

17. Leo E. Strine, Jr., The Dangers of Denial: The Need for a Clear-Eyed Understanding of the Power and Accountability Structure Established by the Delaware General Corporation Law, 50 Wake Forest L. Rev. 761, 772 (2015) (quoting TW Servs., Inc. v. SWT Acquisition Corp., Civ. A. Nos. 10427, 10298, 1989 WL 20290, at*7 (Del. Ch. Mar. $2,1989))$.

18. Id. at 774 .

19. Virtus Capital L.P. v. Eastman Chem. Co., Civ. A. No. 9808-VCL, 2015 WL 580553 , at *16 n.5 (Del. Ch. Feb. 11, 2015) (citation omitted).

20. J.B. Heaton, The "Long Term" in Corporate Law, 72 Bus. Law. 353, 356 (2017); see also Robert Anderson IV, The Long and Short of Corporate Governance, 23 Geo. Mason L. Rev. 19, 20 (2015) ("Even assuming that institutional investors have short investment horizons, the linchpin of the argument-that short-horizon investors will push for policies harmful in the long-term-lacks a foundation. That assertion is inconsistent with basic principles of mainstream financial economics.").

21. See Air Prod. \& Chems., Inc. v. Airgas, Inc., 16 A.3d 48, 124-25 (Del. Ch. 2011) (internal quotation omitted). 
The rights given to stockholders to make proposals and vote on corporate business are premised on the theory that stockholders have an interest in increasing the sustainable profitability of the firm. ${ }^{22}$

In sum, real investors want what we as a society want and we as end-user, individual investors want; which is for corporations to create sustainable wealth. ${ }^{23}$

$[\mathrm{T}] \mathrm{o}$ foster sustainable economic growth, stockholders themselves must act like genuine investors, who are interested in the creation and preservation of long-term wealth, not short-term movements in stock prices. ${ }^{24}$

The focus of many ... institutions on quarterly earnings and other short-term metrics is fundamentally inconsistent with the objectives of most of their end-user investors, people saving primarily for two purposes, to put their kids through college and to fund their own retirements. These end-user investors do not care about quarterly earnings or short-term gimmicks. These end-user investors want corporations to produce sustainable wealth that will be there when they need it. ${ }^{25}$

Put simply, Chief Justice Strine wants corporate boards "to strike the proper balance between the pursuit of profits through risky endeavors and the prudent preservation of value." ${ }^{6}$ These are not the words of currentshareholder-value maximization; these are the words of longevity, of survivability. This is the legal backdrop that supports managers. This is the reality that M.B.A. (and law) students find when they enter the corporate world.

\section{Agency Costs in Corporate Governance}

\section{A. Origins of Agency in Corporate Scholarship}

A huge amount of scholarship in corporate law and financial economics assumes the existence of agency costs; losses that result from expenditures to prevent managerial disloyalty plus the loss of shareholder value from disloyalty that occurs despite these expenditures. The agency-cost view has its roots in challenges, quite vigorous by the 1940s, to the neoclassical economics assumption that firms-especially firms with significant

22. Leo E. Strine, Jr., One Fundamental Corporate Governance Question We Face: Can Corporations Be Managed for the Long Term Unless Their Powerful Electorates Also Act and Think Long Term?, 66 Bus. LAw. 1, 8 (2010) (emphasis added).

23. Id. at 26 (emphasis added).

24. Id. (emphasis added).

25. Id. at 12 (emphasis added).

26. Id. at 18 n.54 (emphasis added). 
Villanova Law Review, Vol. 64, Iss. 2 [2019], Art. 2

market power-act to maximize profits. ${ }^{27}$ Defenders of the profit-maximization paradigm acknowledged the possibility-and possible importance-of nonpecuniary benefits to managers of the firms in the markets the economists studied, ${ }^{28}$ largely because they recognized that managers would maximize their own utility subject to constraints. ${ }^{29}$ That said, it was not obvious in these early days that considering "managerial motivations" would lead away from profit maximization, because both shareholders and managers might desire profit maximization for different reasons. The shareholder would want to "increas[e] the size of his dividends"; the manager would want "profits to ensure the firm's safety, or to make it grow larger, or for various other reasons." 30 Though Professor J.R. Hicks suggested that managers might pursue monopoly so they could enjoy the "quiet life," 31 other economists recognized that external and internal realities (including competition from other managers for the job of the quietlife seeker) could force managers to pursue profit maximization, or something close to it. ${ }^{32}$

By 1963, however, Professor Oliver Williamson had staked out positions that turned managerial motivations into the study of managerial discretion. ${ }^{33}$ Recognizing that any attempt to measure discretionary concerns

27. See T. de Scitovsky, A Note on Profit Maximization and Its Implications, 11 Rev. Econ. STUd. 57 (1943) (developing an analysis to show that profit maximization implies specific preferences on behalf of the entrepreneur that may not hold); see also M.W. Reder, A Reconsideration of Marginal Productivity Theory, 55 J. Pol. Econ. 450,450 (1947) ("The current theory of the firm assumes explicitly that the firm is operated in such a way as to maximize its profits.").

28. See Fritz Malchup, Marginal Analysis and Empirical Research, 36 Amer. Econ. REv. 519, 527 (1946) ("As a matter of fact, the nature, strength and effects of nonpecuniary considerations in business behavior are problems that need to be investigated. One may presume that producing larger production volumes, paying higher wage rates, or charging lower product prices than would be compatible with a maximum of money profits may involve for the business man a gain in social prestige or a certain measure of inner satisfaction.").

29. See Leonid Hurwicz, Theory of the Firm and of Investment, 14 Econometrica 109, 110 (1946) ("Thus the entrepreneur's psychological make-up (somewhat belatedly) enters the picture, and, at least implicitly, profit maximization is replaced by utility maximization."); see also GARy Becker, The Economics of Discrimination (1957).

30. C. Addision Hickman, Managerial Motivation, 19 U. CHI. L. Rev. 794, 798-99 (1952); see also C. Addison Hickman, Managerial Motivation and the Theory of the Firm, 45 Amer. Econ. Rev. 544 (1955) (proposing the study of managerial motivations).

31. J.R. Hicks, The Theory of Monopoly, 3 Econometrica 1, 8 (1935) ("The best of all monopoly profits is a quiet life.").

32. See, e.g., P.W.S. Andrews \& Elizabeth Bruner, Business Profits and the Quiet Life, 11 J. INDUS. ECON. 72, 78 (1962) ("If businesses are to avoid getting into difficulties, we suggest that a devotion to a quiet life will not help them and that they have to have a zealous regard for profits-but not necessarily for profits in the short term.").

33. See Oliver E. Williamson, Managerial Discretion and Business Behavior, 53 Ам. Econ. Rev. 1032 (1963) [hereinafter Managerial Discretion]. Williamson later acknowledged that he was addressing a problem some thought nonexistent. See OLI- 
directly would be too difficult, Williamson assumed the existence of managerial desires for nonpecuniary benefits like "security, power, prestige, and so forth" 34 and then asked "to what activities do these motives give rise?" 35 This was a valid intellectual move that kept with the methodological spirit of the times. It was, by 1963, acceptable among mainstream economists to make assumptions that might be "unrealistic" so long as testable predictions followed. ${ }^{36}$ Williamson's assumption that managers used their discretion to divert resources to themselves and did not put their full efforts into maximizing profits did not strike too many as unrealistic. Defenses of old-style profit maximization theories tended to fall back on their usefulness as a benchmark and the fact they were more testable. ${ }^{37}$ Indeed, it may have been the accepted realism of Williamson's assumptions that excused the empirical failures his theories encountered. ${ }^{38}$

As the 1970s began, Professor Williamson's ${ }^{39}$ theories of managerial discretion were a distinct strand of the economics literature. ${ }^{40}$ Objections

ver E. Williamson, The Economics of Discretionary Behavior: Managerial ObJectives in a Theory of the FiRm 1 (1974) ("To some observers it has been almost self-evident that the opportunities for discretion are extensive and that discretionary behavior is widely exhibited, while to others it has been unclear that in any significant sense such options even exist, much less are exercised.").

34. See Williamson, Managerial Discretion, supra note 33, at 1034.

35. Id.

36. This was the thesis of Milton Friedman's famous essay on methodology in economics. See Milton Friedman, The Methodology of Positive Economics, in Essays in Positive Economics 7 (1953) ("The ultimate goal of a positive science is the development of a 'theory'; or 'hypothesis' that yields valid and meaningful (i.e., not truistic) predictions about phenomena not yet observed.").

37. See H.T. Koplin, The Profit Maximization Assumption, 15 Oxford Econ. PAPERS 130, 130 (1963) ("The profit maximization assumption has long been under attack, chiefly on grounds that it lacks realism. It fails, the argument runs, to take adequate account of alternative desires of the businessman, for power, leisure, social prestige, and similar non-monetary rewards. The possibility of incorporating these benefits into a more general theory of profit maximization has been considered, but rejected, by writers who feel the assumption would thereby be made tautological and/or unusable.").

38. A number of economists found Williamson's empirical findings lacking, because the main prediction of his approach concerning expenses did not hold in the data. See Loretta J. Mester, Testing for Expense Preference Behavior: Mutual versus Stock Savings and Loans, 20 RAND J. Econ. 483, 483 (1983) ("The results of this test do not support earlier conclusions of managerial expense preferences."); Michael Smirlock \& William Marshall, Monopoly Power and Expense-Preference Behavior: Theory and Evidence to the Contrary, 14 BeLL. J. ECON. 166, 167 (1983) (“[Our] results provide no support for the hypothesized relationship between monopoly power and expense-preference behavior.").

39. Other joined him. See, e.g., William J. Baumol, Business Behavior, VAlue AND Growth (1959) (observing that businesses seem to maximize sales subject to achieving a satisfactory level of profits).

40. See Sidney G. Winter, Satisficing, Selection, and the Innovating Remnant, $85 \mathrm{Q}$. J. Econ. 237, 237 (1971) ("The . . . 'managerial,' strand emphasizes the fact that the large size, diffused stock ownership, and market power of the modern corporation leave the management with significant freedom to pursue its own goals, which 
to the testability of the theory found relatively few takers, ${ }^{41}$ and variants on the theory, such as the theory of "X-Inefficiency," grew in the literature as well. ${ }^{42}$ Nevertheless, the real breakthrough was to come elsewhere.

\section{A. Jensen E् Meckling's Agency Theory of the Firm}

Until the mid-to-late 1970s, finance scholars remained committed to the idea that managers maximized current market values. Professors Eugene Fama and Merton Miller argued in 1972 that "despite many years of controversy, [it has not] yet been demonstrated that the market value rule leads to predictions that are so widely at variance with observed management behavior as to rule it out, even as a first approximation . . .."43 Moreover, other economists had argued that managers within the firm could coordinate the actions of labor to arrive at efficient outcomes. ${ }^{44}$ In other words, it was not yet time, in finance at least, to embrace a managerial-discretion view instead of a loyal-manager view.

The first step in that direction within finance was taken, almost as an afterthought, by Professor Stephen Ross, who advanced a general economic analysis of agency theory along with a suggestion that it might apply to managers and shareholders: 45

To mention one more path of interest-in a world of true uncertainty where adequate contingent markets do not exist, the manager of the firm is essentially an agent of the shareholders. It can, therefore, be expected that an understanding of the agency relationship will aid our understanding of this difficult question. ${ }^{46}$

Jensen and Meckling pursued Ross's suggestion at full speed, setting out an ambitious agenda for an agency approach in their landmark 1976 paper, Theory of the Firm: Managerial Behavior, Agency Costs and Ownership Structure. ${ }^{47}$ Jensen and Meckling sought to develop a theory of ownership

are not correctly represented as maximization of profit on behalf of the stockholders.”).

41. See R. Rees, A Reconsideration of the Expense Preference Theory of the Firm, 41 ECONOMICA 295, 307 (1974) (concluding, after extensive analysis that "difficulties would arise in testing the expense preference theory against competing theories of the firm").

42. See Harvey Leibenstein, Aspects of X-Inefficiency Theory of the Firm, 6 BeLL J. EcON. 580, 603-04 (1975) ("Because of self-interest implicit in the degree of constraint concern, individuals are unlikely to choose effort positions which maximize their contribution to firm output.").

43. See Fama \& Miller, supra note 15, at 75.

44. See Armen A. Alchian \& Harold Demsetz, Production, Information Costs, and Economic Organization, 62 Amer. Econ. Rev. 777 (1972).

45. See Stephen A. Ross, The Economic Theory of Agency, 63 Amer. Econ. Rev. 134 (1973).

46. Id. at 138 .

47. Michael C. Jensen \& William H. Meckling, Theory of the Firm: Managerial Behavior, Agency Costs and Ownership Structure, 3 J. Fin. Econ. 305 (1976). 
as split between insiders and outsiders. ${ }^{48}$ They summarily dismissed prior work on the theory of the firm, including Williamson's. ${ }^{49}$ Then, in setting out their theory, they "define[d] agency costs as the sum of: (1) the monitoring expenditures by the principal, (2) the bonding expenditures by the agent, [and] (3) the residual loss."50

The impact of Jensen and Meckling's paper came mostly from its assertion that "the relationship between the stockholders and manager of a corporation fit the definition of a pure agency relationship . . ."51 They offered a remarkably elastic theory of how agency costs could arise in the corporation:

The magnitude of the agency costs discussed above will vary from firm to firm. It will depend on the tastes of managers, the ease with which they can exercise their own preferences as opposed to value maximization in decision making, and the costs of monitoring and bonding activities. The agency costs will also depend upon the cost of measuring the manager's (agent's) performance and evaluating it, the cost of devising and applying an index for compensating the manager which correlates with the owner's (principal's) welfare, and the cost of devising and enforcing specific behavioral rules or policies. ${ }^{52}$

If this statement came close to an admission that the agency-cost paradigm was too flexible, with too many degrees of freedom, and therefore capable of explaining most anything, Jensen and Meckling did not admit it. But the problem is there for all to see. An outcome-often one that is far from obviously tied to an agency problem-that seems reasonable can

48. Id. at $306,312-13$.

49. Id. at 307 .

50. Id. at 308. While Jensen and Meckling apparently were unaware of it, that exact view of monitoring costs was earlier published by an assistant professor of political science at Ohio State University, Barry Mitnick, who called it investments in "policing":

Assume that the principal for some reason wishes to police his agent. Note that one form of policing would be encouraging the agent to hold the fiduciary norm; we will not, however, consider here the actual mode of policing. Assume that the principal has no outside source of resources to devote to a policing mechanism. He must then divert some of the total discretionary resources potentially available to be distributed towards his own and the agent's ends into a policing apparatus.

Barry M. Mitnick, The Theory of Agency: The Policing "Paradox" and Regulatory Behavior, 24 Pub. Choice 27, 31 (1975). Mitnick also anticipated the third component of Jensen and Meckling's agency costs-the residual loss-showing that policing might solve only part of the loss in an agency relationship. Id. at 33-36. Bonding expenditures by the agent were the only novel contribution in the Jensen and Meckling definition of agency costs.

51. See Jensen \& Meckling, supra note 47, at 309.

52. Id. at 328 . 
always be explained by solutions to the asserted agency-cost problem, ${ }^{53}$ an outcome that seems unreasonable can always be explained by residual losses from agency costs that could not be controlled. When all these arguments hinge on asserted costs that are unobservable, the resulting explanations may be no more than "just so stories." ${ }_{4}$

The agency-cost paradigm provides an inviting framework for theorizing about corporations and their managers, but, as the opening quote by Stephen Ross puts it, "it fares poorly if judged by asking what it is that would be a counter observation or count as evidence against it." ${ }^{55}$ For example, managers who use cash flow to acquire companies can be characterized as empire-builders wasting shareholder funds, ${ }^{56}$ while managers who do not expand their businesses can be characterized as being unfaithful by enjoying the "quiet life." 57 Nothing seems beyond the explanatory power of agency costs, but not in a good way.

\section{B. The Consolation of Agency}

When Jensen and Meckling confined their attention to "the analysis of agency costs generated by the contractual arrangements between the owners and top management of the corporation," 58 they presumably knew that shareholders do not enter into such arrangements with the corporation's top management. To get around this inconvenience, they introduced what has become, arguably, one of the more troublesome turns of phrase ever used in law and economics, the nexus of contracts:

It is important to recognize that most organizations are simply legal fictions which serve as a nexus for a set of contracting relationships among individuals .... . The private corporation or firm is simply one form of legal fiction which serves as a nexus for contracting relationships and which is also characterized by the existence of divisible residual claims on the assets and cash flows of the organization which

53. See Ronald W. Anderson, M. Ceclia Bustamante, Stephane Guibaud \& Mihail Zervos, Agency, Firm Growth, and Managerial Turnover, 73 J. Fin. 419, 422 (2018) (modeling an agency problem, and then interpreting data as consistent with the model's prediction of an optimal contract).

54. Rudyard Kipling, Just So Stories (1902) (illustrating idea that unexplainable truths must be accepted as "just so").

55. Ross, supra note 1 , at 334.

56. See Ronald W. Masulis, Cong Wang \& Fei Xie, Agency Problems at Dual-Class Companies, 64 J. FIN. 1697, 1722 (2009) ("Specifically, as the insider control rightscash flow rights divergence becomes larger, outside shareholders raise the discount on an extra dollar of corporate cash holdings, CEOs receive greater compensation, and managers engage in more inefficient empire-building activities such as acquisitions and large capital expenditures.").

57. See Marianne Bertrand \& Sendhil Mullainathan, Enjoying the Quiet Life? Corporate Governance and Managerial Preferences, 111 J. PoL. Econ. 1043, 1043 (2003) ("Our results suggest that active empire building may not be the norm and that managers may instead prefer to enjoy the quiet life.").

58. See Jensen \& Meckling, supra note 47, at 309. 
can generally be sold without permission of the other contracting individuals .... Viewed this way, it makes little or no sense to try to distinguish those things which are "inside" the firm (or any other organization) from those things that are "outside" of it. There is in a very real sense only a multitude of complex relationships (i.e., contracts) between the legal fiction (the firm) and the owners of labor, material and capital inputs and the consumers of output. 59

It is difficult to overstate the importance of Jensen and Meckling's nexus of contracts assertion in explaining the rise of agency theory in corporate law and finance. ${ }^{60}$ Disregarding the corporation as a fictional entity encouraged economists to avoid learning corporate law in their study of the firm. Economists could study the interactions between individuals in disregard of the firm and perhaps even in disregard of notions of "ownership" altogether. ${ }^{61}$ Unfortunately, this sort of law-free analysis often misses the most basic legal restrictions that control the asserted behavior under study. ${ }^{62}$

Moreover, Jensen and Meckling's nexus of contracts assertion was so vague that agency theory offered the chance for debate about corporate finance to occur in narrative form equally available to legal scholars and economists alike, a true advantage for interdisciplinary acceptance. At a time when asset-pricing research presented a relatively high mathematical bar for those outside finance, agency theory as applied in corporate law and finance provided a creative framework for almost endless speculation about important matters, often without any mathematics at all. Finance scholars extended their influence by couching arguments non-mathematically, such as Michael Jensen's elegantly short article arguing that debt was good because it absorbed free cash flow, and that takeovers disciplined

59. Id. at 310-11 (emphasis in original).

60. The nexus of contracts assertion has long the subject of criticism by legal scholars. See, e.g., Victor Brudney, Corporate Governance, Agency Costs, and the Rhetoric of Contract, 85 Colum. L. Rev. 1403, 1444 (1985) ("Analyzing the corporation in terms of a 'nexus of contracts,' and even in terms of agency costs, casts the problem in a framework that implies less managerial discretion and more effective remedial options for investors than institutional impediments permit. The analyses embody serious descriptive inaccuracies, which, in turn, infect the normative consequences implicitly suggested by a regime of private autonomy and thereby make them inapposite for a world in which one of the 'parties' assumed to be able to bargain is a collectivity of widely dispersed individuals and the other is a coherent group."); William W. Bratton, Jr., The "Nexus of Contracts" Corporation: A Critical Appraisal, 74 CoRnell L. Rev. 407 (1989) (criticizing the nexus of contracts view).

61. See Eugene F. Fama, Agency Problems and the Theory of the Firm, 88 J. Pol. ECON. 288, 290 (1980) ("In this 'nexus of contracts' perspective, ownership of the firm is an irrelevant concept.").

62. See Stewart C. Myers \& Raghuram Rajan, The Paradox of Liquidity, 113 Q. J. ECON. 733 (1998). The model of Myers and Rajan ignores the impact of fraudulent transfer law in preventing nearly all the problems they identify. Much of the "property rights" literature suffers from this problem. 
Villanova Law Review, Vol. 64, Iss. 2 [2019], Art. 2

managers who otherwise would waste free cash flow. ${ }^{63}$ Legal scholars could access the economics literature with narratives built on agency arguments. ${ }^{64}$ Most debate about the takeovers of the 1980s occurred in the framework of mathematics-free applications of agency arguments. ${ }^{65}$

The influence of agency theory is awe-inspiring. Jensen and Meckling's article is the third most cited in major economics journals according to a leading citation study ${ }^{66}$ Decades after Jensen and Meckling's article, it is still common to motivate research in opening paragraphs by reference to their theoretical propositions. ${ }^{67}$

\section{The False God of Agency}

\section{A. The Paramount (but Ignored) Role of Corporate Law}

Despite its influence, more than forty years of active research have yet to uncover any good evidence that managers are systematically disloyal and that the focuses of agency theories-financing decisions, investment decisions, and the like-are best understood as related to agency problems. Instead, there are good reasons to think that systematic, intentionally disloyal behavior is highly unlikely. ${ }^{68}$ Early experimental evidence suggested that investigation and sanctions eliminate most shirking of the kind asserted by Jensen and Meckling. ${ }^{69}$ This matters because "[m] ost of corporate law is concerned with the array of substantive rules and proce-

63. See Jensen, supra note 2, at 323.

64. See Frank H. Easterbrook, Two Agency-Cost Explanations of Dividends, 74 Ам. ECON. Rev. 650 (1984).

65. See Frank H. Easterbrook \& Daniel R. Fischel, Takeover Bids, Defensive Tactics, and Shareholders' Welfare, 36 Bus. Law. 1733, 1736 (1981) ("These 'agency costs' are an inevitable consequence of the separation of ownership and control in the large publicly held corporation.”); Frank H. Easterbrook \& Daniel R. Fischel, Corporate Control Transactions, 91 YALE L. J. 698, 705 (1982) ("Corporate control transactions can reduce agency costs if better managers obtain control of the firm's assets or if they alter the incentive structure facing existing managers.").

66. See E. Han Kim, Adair Morse \& Luigi Zingales, What Has Mattered to Economics Since 1970, 20 J. Econ. Persp. 189, 192 (2006).

67. See Matthew O'Connor \& Matthew Rafferty, Corporate Governance and Innovation, 47 J. Fin. Quantitative Analysis 397, 397 (2012) ("Jensen and Meckling (1976) show that agency problems are an inherent part of modern corporations with diffuse ownership structures. The agency problem arises because the executives who run the firm are not the same individuals as the shareholders. As long as it is difficult or costly for the shareholders to monitor the executives, the executives will have an incentive to engage in behavior that maximizes their utility rather than the wealth of the shareholders.").

68. Attempts to measure agency costs directly have been unconvincing, partly because they must use only small businesses for comparison. See James S. Ang, Rebel A. Cole \& James Wuh Lin, Agency Costs and Ownership Structure, 55 J. FIN. 81, 104 (2000) ("[U]s[ing] data on small businesses to examine how agency costs vary with a firm's ownership structure.").

69. See Douglas V. DeJong, Robert Forsythe, Russell J. Lundholm \& Wilfred C. Uecker, A Laboratory Investigation of the Moral Hazard Problem in an Agency Relationship, 23 J. Acct. Res. 81 (1985). 
dural devices that are aimed at controlling managerial slack and diversion while preserving adequate discretion to carry out business operations efficiently."70 It simply may be the case that the plain-vanilla constraints of corporate law are just too powerful to leave much to do for debt, large shareholders, and takeovers in controlling intentional managerial disloyalty, certainly among large U.S. corporations. If so, there is considerable irony here. As argued above, Jensen and Meckling's disregard of the firm as a fiction relieved economists from studying the very mechanisms of corporate law that may control most problems that arise from self-interested utility maximization by the corporation's directors and officers.

Writers too easily dismiss the power of shareholder derivative suits. ${ }^{71}$ An active plaintiffs' bar and sophisticated investors challenge compensation decisions, ${ }^{72}$ efforts to usurp corporate opportunities, ${ }^{73}$ gross mismanagement, ${ }^{74}$ go-private transactions, ${ }^{75}$ and transactions that strip assets from the corporation. ${ }^{76}$ Research demonstrates the importance of such litigation in controlling much of the behavior targeted in agency-cost theories. ${ }^{77}$

70. Robert C. Clark, Corporate Law xxiii (1986).

71. See Jill E. Fisch, The Overstated Promise of Corporate Governance, 77 U. CHI. L. Rev. 923, 937 (2010) ("The business judgment rule has the practical effect of limiting state law litigation to transactions involving self-dealing or conflicts of interest. As a result of this limitation, it is unsurprising that empirical studies of derivative litigation find it to be relatively ineffective."). Of course, effectiveness in transactions involving self-dealing and conflict of interest is effectiveness in a significant part (though not all) of what agency theory claims is at stake.

72. See Espinoza v. Zuckerberg, 124 A.3d 47, 66 (Del. Ch. 2015) ("The entire fairness standard of review requires defendants to establish that the transaction was the product of both fair dealing and fair price. Because defendants relied solely on a ratification defense, they did not attempt to produce evidence of entire fairness sufficient to show an entitlement to judgment as a matter of law, nor have they demonstrated that there is no genuine issue of material fact as to the entire fairness of the 2013 Compensation.”).

73. See In re Riverstone Nat'l, Inc. Stockholder Litig., No. CV 9796-VCG, 2016 WL 4045411, at*17 (Del. Ch. July 28, 2016) (denying motion to dismiss claim that merger extinguished claim of usurpation of a corporate opportunity).

74. See Benchmark Capital Partners VII v. Kalanick, No. 2017-0575, 2018 WL 587180 , at *1 (Del. Ch. Jan. 26, 2018) (unpublished order dismissing with prejudice).

75. See Icahn Partners LP v. Zyskind, No. 2018-0358 (Del. Ch. filed May 21, 2018). (challenging the go-private transaction of AmTrust Financial Services, Inc.).

76. See GPM Investments v. Sun Capital Partners IV, No. 1:18-cv-00796 (D. Del. filed May 25, 2018) (challenging transactions by private equity owner).

77. See Dain C. Donelson \& Christopher G. Yust, Litigation Risk and Agency Costs: Evidence from Nevada Corporate Law, 57 J. L. \& ECON. 747, 750 (2014) ("[E]vidence that corporate officer and director litigation risk appears to be a powerful governance mechanism that significantly enhances firm value and constrains managerial behavior. Our findings highlight the importance of litigation risk as a mechanism to mitigate agency costs between corporate insiders and outside shareholders.”). 
Villanova Law Review, Vol. 64, Iss. 2 [2019], Art. 2

\section{B. That Little Matter of Dog-Eat-Dog Competition}

There is no question that adding the assumption of managerial disloyalty to models where shareholders want value maximization can generate the subtlest of academic contests. Paper after paper builds complex agency explanations of important corporate matters. ${ }^{78}$ But virtually none of this research confronts the objection that real-world managers face brutal business competition that constrains the ability to shirk and divert. ${ }^{79}$ Jensen and Meckling admitted the problem, although buried in footnote thirty of their paper: "Where competitors are numerous and entry is easy, persistent departures from profit maximizing behavior inexorably leads to extinction. Economic natural selection holds the stage." 80

But having admitted this devastating possibility, they dismiss it with circular argument, claiming:

$[\mathrm{T}]$ he existence of competition in product and factor markets will not eliminate the agency costs due to managerial control problems as has often been asserted ... . If my competitors all incur agency costs equal to or greater than mine I will not be eliminated from the market by their competition. ${ }^{81}$

Assuming that agency costs will exist despite competition because agency costs exist everywhere is unpersuasive. This argument is yet another example of the unconstrained nature of agency-cost theories, but one that persuades only the believers.

\section{A Path Forward}

There is a path out of the cult of agency. It is a path that will lead to better scholarship on corporate governance, scholarship that also is likely to help directors and officers better manage corporate assets. It should not surprise us that agency theories have so little influence outside the academy. The notion of corporate directors and managers looking for

78. See Rajesh K. Aggarwal \& Andrew A. Samwick, Why Do Managers Diversify Their Firms? Agency Reconsidered, 58 J. Fin. 71, 73 (2003) ("We find that firm performance is increasing in incentives and decreasing in diversification, consistent with the previous literature. More importantly, we find evidence that diversification is increasing in incentives .... We show that the negative relationship found in those studies is the result of unobserved, firm-specific factors. We control for these factors by using firm-level fixed effects. The result that diversification is increasing in incentives suggests that changes in incentives and diversification are due to changes in the private benefits associated with diversification.").

79. See Rui Albuquerque \& Neng Wang, Agency Conflicts, Investment, and Asset Pricing, 63 J. FIN. 1 (2008) (developing a dynamic model of a firm without modeling competitors); Peter DeMarzo \& Michael J. Fishman, Agency and Optimal Investment Dynamics, 20 Rev. Fin. Stud. 151 (2007) (same); Peter M. DeMarzo, Michael J. Fishman, Zhiguo He \& Neng Wang, Dynamic Agency and the q Theory of Investment, 67 J. FIn. 2295 (2012) (same); Boris Nikolov \& Toni M. Whited, Agency Conflicts and Cash: Estimates from a Dynamic Model, 69 J. FIN. 1883 (2014) (same).

80. Jensen \& Meckling, supra note 47, at 329 n.30.

81. Id. at 330 . 
every self-serving opportunity to shirk their duties in favor of flying the corporate jet to an Aspen ski vacation-or acquire the next unnecessary company to build their empire like a Lego project-strikes directors, officers, and their professional advisers, like bankers and lawyers, as flatly untrue. It is possible, of course, to find isolated examples of corporate management that indulges in excessive perks and avoids tough decisions. Nevertheless, most top corporate managers-up before dawn, sacrificing family relationships and health to their work, and fighting day after day in competitive markets-react with justified scorn that academic theory views them as people who avoid the search for profitable projects "because it requires too much trouble or effort on their part to manage or to learn about new technologies ... result[ing] in the value of the firm being substantially lower than it otherwise could be."82 The path forward can combine two things: (1) better knowledge (or attention to knowledge already acquired) of how corporate law currently encourages deviations from shareholder value maximization, and (2) the application of behavioral corporate finance. I already have addressed the flexibility of corporate law. I turn now to behavioral corporate finance.

Unlike agency theory, where no evidence shows that managers are intentionally disloyal, a great deal of evidence shows that managers are miscalibrated. ${ }^{83}$ And by contrast to agency costs, it is possible to measure optimism. ${ }^{84}$ Work on managerial optimism builds on results in the psychology literature demonstrating that individuals tend to make systematically biased probability assessments when estimating event likelihood. ${ }^{85}$ Optimism is particularly well suited to corporate governance because evidence shows that individuals are not only confident in the validity of their current beliefs but also are confident that others, given sufficient time, will come around to seeing the correctness of those beliefs as well. ${ }^{86}$ The managerial-optimism approach already has made great strides in the last

82. Id. at 313 .

83. See, e.g., Itzhak Ben-David, John R. Graham \& Campbell R. Harvey, Managerial Miscalibration, 128 Q. J. ECON. 1547 (2013) (presenting survey results showing that managers are severely miscalibrated in their beliefs); John R. Graham, Campbell R. Harvey \& Manju Puri, Managerial Attitudes and Corporate Actions, 109 J. FIn. ECON. 103 (2013) (providing evidence that CEO's behavioral traits such as optimism and managerial risk-aversion are related to corporate financial policies); Ulrike Malmendier \& Geoffrey Tate, Behavioral CEOs: On the Role of Managerial Overconfidence, $29 \mathrm{~J}$. Econ. Persp. 37, 57 (2015) ("A large and growing body of evidence suggests that a substantial share of top corporate executives exhibit symptoms of overconfidence in their decisions.").

84. See Manju Puri \& David T. Robinson, Optimism and Economic Choice, $86 \mathrm{~J}$. FIN. ECON. 71 (2007) (examining measures of optimism).

85. See Shelly E. Taylor \& Jonathan D. Brown, Illusion and Well-Being: A Social Psychological Perspective on Mental Health, 103 Psychol. Bull. 193 (1988); Neil Weinstein, Unrealistic Optimism About Future Life Events, 39 J. Personality \& Soc. Psychol. 806 (1980).

86. See Todd Rogers, Don A. Moore \& Michael I. Norton, The Belief in a Favorable Future, 28 Psychol. SCI. 1290 (2017). 
Villanova Law Review, Vol. 64, Iss. 2 [2019], Art. 2

two decades, providing more parsimonious predictions and evidence that does not rely on unobservable information asymmetries and agency costs. ${ }^{87}$ It explains the preference managers have for internal finance and why free cash flow is dangerous for firms with optimistic managers. ${ }^{88}$ It predicts overpayment by managers in mergers and acquisitions and other corporate investment patterns. ${ }^{89}$ It also explains more financial misstatements than intentional activity. ${ }^{90}$ In addition, managerial optimism explains why managers dislike paying dividends but like repurchasing stock. ${ }^{91}$ Managerial optimism also explains security issuances and financ-

87. For surveys of behavioral corporate finance, see Malcolm Baker, Richard Ruback \& Jeffrey Wurgler, Behavioral Corporate Finance: A Survey, in vol. 1, Handbook of Corporate Finance: Empirical Corporate Finance 145 (B. Espen Eckbo ed., 2007) (surveying behavioral corporate finance); Malcolm Baker \& Jeffrey Wurgler, Behavioral Corporate Finance: An Updated Survey, in HandBook of THE EconomICS OF Finance 357 (G.M. Constantinides, M. Harris, \& R.M. Stulz, eds., 2013) (same); Simon Gervais, Capital Budgeting and Other Investment Decisions, in BeHAvioral Finance: Investors, Corporations, and Markets 413 (H. Kent Baker \& John R. Nofsinger eds., 2010) (surveying literature on behavioral biases showing that biased managers overinvest their firm's free cash flows, initiate too many mergers, start more firms and more novel projects, and tend to stick with unprofitable investment policies longer).

88. See J.B. Heaton, Managerial Optimism and Corporate Finance, 31 Fin. Mgmt. 33 (2002) (showing that managerial optimism predicts pecking-order capital structure preferences and problems with free cash flow); Dirk Hackbarth, Managerial Traits and Capital Structure Decisions, 43 J. Fin. \& Quantitative Analysis 843 (2008) (studying the impact of managerial optimism on capital structure choices); Yuehhsiang Lin, Shing-yang Hu \& Ming-shen Chen, Testing Pecking Order Prediction From the Viewpoint of Managerial Optimism: Some Empirical Evidence from Taiwan, 16 PACIFICBASIN FIN. J. 160 (2008) (confirming predictions of Heaton's model that optimistic managers exhibit greater net-debt-issue/financing-deficit sensitivities than do nonoptimistic ones); Winifred Huang-Meier, Neophytos Lambertides \& James M. Steeley, Motives for Corporate Cash Holdings: The CEO Optimism Effect, 47 Rev. QuantiTATIVE Fin. \& ACCT. 699 (2016) (finding, consistent with predictions of managerial optimism, that optimistic managers are reluctant to use external funds and hoard cash for growth opportunities, use more cash for capital expenditure and acquisitions, and save more cash in bad times).

89. See Yueh-hsiang Lin, Shing-yang Hu \& Ming-shen Chen, Managerial Optimism and Corporate Investment: Some Empirical Evidence from Taiwan, 13 PACIFIC-BASIN Fin. J. 523 (2005) (testing J.B. Heaton's managerial optimism on Taiwanese market data and confirming its predictions); Ulrike Malmendier \& Geoffrey Tate, CEO Overconfidence and Corporate Investment, 60 J. Fin. 2661 (2005) (finding that the investment of overconfident CEOs is more responsive to cash flow).

90. See Catherine M. Schrand \& Sarah L.C. Zechman, Executive Overconfidence and the Slippery Slope to Financial Misreporting, 53 J. Acct. \& Econ. 311 (2012) (finding that three quarters of financial misstatements reflect an optimistic bias that is not necessarily intentional); see also Anwer S. Ahmed \& Scott Duellman, Managerial Overconfidence and Accounting Conservatism, 51 J. AсCT. REs. 1 (2013) (finding robust evidence of a negative relation between CEO overconfidence and accounting conservatism).

91. See Sanjay Deshmukh, Anand M. Goel \& Keith M. Howe, CEO Overconfidence and Dividend Policy, 22 J. Fin. InTERmediation 440 (2013) (finding that the level of dividend payout is about one-sixth lower in firms managed by CEOs who are more likely to be optimistic, consistent with the preference of such managers for internal financing); Pei-Gi Shu, Yin-Hua Yeh, Tsui-Lin Chiang \& Jui-Yi Hung, 
ing choices, ${ }^{92}$ as well as the investment choices managers make with the funds they raise. ${ }^{93}$

Moreover, managerial optimism, while quite parsimonious, allows for a rich set of interactions among outsiders (whether large shareholders or hedge fund activists), directors, and the firm's managers. ${ }^{94}$ The managerial optimism approach may also help explain the role of outsiders in corporate governance, perhaps the single-greatest claim of the agency approach. ${ }^{95}$ Researchers have argued that organizational optimism is best alleviated by introducing an "outside" view, one capable of identifying all

Managerial Overconfidence and Share Repurchases, 13 InT'L REv. FIN. 39 (2013) (finding that managerial overconfidence is positively correlated with the intensity of share repurchasing, which is measured by scale, execution, frequency, and the difference between the announced price and post-execution price).

92. See Ronghong Huang, Kelvin Jui Keng Tan \& Robert W.Faff, CEO Overconfidence and Corporate Debt Maturity, 36 J. Corp. FIN. 93 (2016) (finding that firms with overconfident CEOs tend to adopt a shorter debt maturity structure by using a higher proportion of short-term debt (due within 12 months)); Po-Hsin Ho, Chia-Wei Huang, Chih-Yung Lin \& Ju-FangYen, CEO Overconfidence and Financial Crisis: Evidence from Bank Lending and Leverage, 120 J. FIn. Econ. 194 (2016) (finding that banks with overconfident CEOs were more likely to weaken lending standards in advance of a crisis); Luís Santos-Pinto \& Michele Dell'Era, Entrepreneurial Optimism and the Market for New Issues, 58 Int'L Econ. Rev. 383 (2017) (examining the impact of optimism in new issues of equity); Sanaz Aghazadeh, Lili Sun, Qian Wang \& Rong Yang, Investors' Perception of CEO Overconfidence: Evidence from the Cost of Equity Capital, Rev. Quantitative Fin. \& Acct (forthcoming) (finding evidence that managerial optimism impacts the cost of equity).

93. See Dirk Hackbarth, Determinants of Corporate Borrowing: A Behavioral Perspective, 15 J. CorP. FIn. 389 (2009) (applying a real options framework to analyze the effects of managerial optimism and overconfidence on the interaction between financing and investment decisions); Ulrike Malmendier, Geoffrey Tate \& Jon Yan, Overconfidence and Early-life Experiences: The Effect of Managerial Traits on Corporate Financial Policies, 66 J. FIN. 1687 (2011) (finding that measurable managerial characteristics have significant explanatory power for corporate financing decisions); Chih-Yung Wang, Yu-Fen Chen \& Chia-Wen Yu, Managerial Optimism and Post-Financing Stock Performance in Taiwan: A Comparison of Debt and Equity Financing, 119 ECON. LetTERs 332 (2013) (presenting evidence that corporate financing decisions in Taiwan are driven by managerial optimism).

94. See T. Colin Campbell, Michael Gallmeyer, Shane A. Johnson, Jessica Rutherford \& Brooke W. Stanley, CEO Optimism and Forced Turnover, 101 J. Fin. ECON. 695 (2011) (analyzing suboptimal and optimal levels of managerial optimism); Gilles Hilary, Charles Hsu, Benjamin Segal \& Rencheng Wang, The Bright Side of Managerial Over-Optimism, 62 J. AсCT. \& ECON. 46 (2016) (managerial optimism leads to additional effort that improves firm profitability and market value); Adam C. Kolasinski \& Xu Li, Can Strong Boards and Trading Their Own Firm's Stock Help CEOs Make Better Decisions? Evidence from Acquisitions by Overconfident CEOs, $48 \mathrm{~J}$. QuANTITATIVE \& Fin. 1173 (2013) (finding that independent boards help overconfident CEOs avoid honest mistakes when they seek to acquire other companies); Clemens A. Otto, CEO Optimism and Incentive Compensation, 114 J. FIN. EcON. 366 (2014) (showing how firms can take advantage of optimistic managers by adjusting compensation contracts); Jian Wang, Jiliang Sheng \& Jun Yang, Optimism Bias and Incentive Contracts in Portfolio Delegation, 33 Econ. Modelling 493 (2013) (finding that optimistic managers take more risk than fully rational managers).

95. See Andrei Shleifer \& Robert W. Vishny, Large Shareholders and Corporate Control, 94 J. Pol. Econ. 461 (1986). 
Villanova Law Review, Vol. 64, Iss. 2 [2019], Art. 2

the reasons the "inside" view might be wrong. ${ }^{96}$ Outsiders are capable of drawing managerial attention to information that might indicate that their perceptions are wrong. ${ }^{97}$ The push in corporate governance circles for outside directors and outside chairmen of the board is consistent with this prescription.

Overall, it seems likely that behavioral corporate finance could displace agency theories in their entirety. Several mechanisms are commonly asserted to control agency costs, including shareholdings by insiders, institutions, and large blockholders, the presence of outside directors, debt, competition from other managers, and the market for corporate control. $^{98}$ All of these are amenable to-and most have already been analyzed through the lens of-managerial optimism.

\section{Conclusion}

Corporate governance should abandon agency theory. Managers are not agents and shareholders are not principals. The corporation creates a separation of ownership (of shares) and ownership (of assets) that is critical to the success of the large firm. Ignoring these realities has generated an enormous literature with little relevance to actual corporate governance problems. Agency theory sought to explain deviations from shareholder-value maximization with unobservable agency costs. Thus, for any phenomenon under study, at least two answers were always available. The current situation was optimal because some device or other controlled the agency problem, or the current situation was suboptimal (or optimal at the margin for the spend on monitoring and bonding costs) because agency problems could not be controlled at acceptable cost. This is not the first article to criticize the agency approach, ${ }^{99}$ but prior criticism has not gone far enough. We should end the cult of agency.

I propose that the study of corporate governance change focus. Behavioral corporate finance holds the promise of bold advances that will better explain corporate behavior, better integrate with existing corporate

96. See Daniel Kahneman \& Dan Lovallo, Timid Choices and Bold Forecasts: A Cognitive Perspective on Risk Taking, 39 Mgmt. Sci. 17 (1993).

97. See Alon Brav, Wei Jiang, Frank Partnoy \& Randall Thomas, Hedge Fund Activism, Corporate Governance, and Firm Performance, 63 J. FIN. 1729 (2008) (discussing hedge fund activism); Alon Brav, Wei Jiang \& Hyunseob Kim, Hedge Fund Activism: A Review, 4 Foundations and Trends in Fin. (2010) (same).

98. See Anup Agrawal \& Charles R. Knoeber, Firm Performance and Mechanisms to Control Agency Problems between Managers and Shareholders, 31 J. Fin. Quantitative ANALYSIS 377 (1996).

99. See Claire A. Hill \& Brett H. McDonnell, The Agency Cost Paradigm: The Good, the Bad, and the Ugly, 38 Seattle L. Rev. 561, 562 (2015) ("We think that [the agency] paradigm stands quite weakened intellectually, and perhaps politically and legally as well (though perhaps not!)."); Michael J. Meurer, Law, Economics, and the Theory of the Firm, 52 Buff. L. Rev. 727, 731 (2004) ("The nexus of contract approach to corporate law has generated valuable insights, but this literature has created the false impression that agency theory captures the essence of the theory of the firm."). 
law, and provide guidance to directors and officers that is of use to them. It is time to let go of the theory of "plush carpets and company airplanes ... pursuing pet projects, and so on"100 and get on with the work of understanding real corporate governance in a way the working world can take seriously.

100. Andrei Shleifer \& Robert W. Vishny, A Survey of Corporate Governance, $52 \mathrm{~J}$. Fin. 737, 742 (1997); see also David Yermack, Flights of Fancy: Corporate Jets, CEO Perquisites, and Inferior Shareholder Returns, 80 J. FIN. ECON. 211, 211 (2006) ("Regression analysis finds no significant associations between CEOs' perquisites and their compensation or percentage ownership, but variables related to personal CEO characteristics, especially long-distance golf club memberships, have significant explanatory power for personal aircraft use."). 
